\title{
Immunohistochemical staining of Langerhans cells in HPV-positive and HPV-negative cases of oral squamous cells carcinoma
}

\author{
Karuza Maria Alves PEREIRA ${ }^{1}$, Rosilene Calazans SOARES ${ }^{2}$, Márcio Campos OLIVEIRA ${ }^{3}$ Leão Pereira PINTO4 , \\ Antônio de Lisboa Lopes COSTA ${ }^{4}$
}

\author{
1- DDS, MSc, PhD, Professor, School of Dentistry, Federal University of Ceará - Campus Sobral, Sobral, CE, Brazil. \\ 2- DDS, MSc, PhD, Professor, Department of Morphology, Federal University of Sergipe, Aracaju, SE, Brazil. \\ 3- DDS, MSc, PhD, Professor, School of Dentistry, State University of Feira de Santana, Feira de Santana, BA, Brazil. \\ 4- DDS, MSc, PhD, Professor, Graduate Program of Oral Pathology, Federal University of Rio Grande do Norte, Natal, RN, Brazil.
}

Corresponding address: Prof. Dr. Antônio de Lisboa Lopes Costa - Departamento de Odontologia da Universidade Federal do Rio Grande do Norte Av: Senador Salgado Filho 1787 - Lagoa Nova - Natal, RN - 59056-000 - Brasil - Phone/Fax: +55-84-3215-4138 - e-mail: antoniodelisboa@uol.com.br/ karuzaalves@yahoo.com.br/

Received: July 04, 2009 - Modification: April 30, 2010 - Accepted: October 26, 2010

\section{ABSTRACT}

\begin{abstract}
The Human Papillomavirus (HPV) has been strongly implicated in development of some cases of oral squamous cell carcinoma (OSCC). However, the immunological system somehow reacts against the presence of this virus. Among the cells involved in such mechanism of defense Langerhans cells (LC) stand out, which are responsible for processing and presenting antigens. Objectives: The purposes of this study were to investigate the presence of HPV DNA and to evaluate the immunohistochemical reactivity for Langerhans cells between HPV-positive and HPV-negative OSCC. Twenty-seven cases of OSSC were evaluated. Material and Methods: DNA was extracted from paraffin-embedded tissue samples and amplified by Polymerase Chain Reaction (PCR) for the detection of HPV DNA. Viral typing was performed by dot blot hybridization. Immunohistochemistry was performed by the Streptavidin-biotin technique. Results: From the 27 cases, 9 (33.3\%) were HPVpositive and 18 (66.0\%) HPV-negative. HPV 18 was the most prevalent viral type (100\% cases) and infection with HPV-16 (co-infection) was detected in only 1 case. In the OSCC specimens examined, immunoreactivity to S-100 antibody was detected in all cases, with a mean number of $49.48 \pm 30.89$ Langerhans cells positive for immunostaining. The mean number of immunostained Langerhans cells was smaller in the HPV-positive cases (38 cells/case) than in the HPV-negative cases (42.5 cells/case), but this difference was not significant $(p=0.38)$. Conclusions: The low frequency of detection of HPV DNA in OSCC indicates a possible participation of the virus in the development and progression of only a subgroup of these tumors. There was no association between the immunohistochemical labeling for Langerhans cells (S-100+) and HPV infection of in OSSC. These findings suggest that the presence of HPV in such OSCC cases could not alter the immunological system, particularly the Langerhans cells.
\end{abstract}

Key words: HPV. Carcinoma. Langerhans cells. Polymerase chain reaction. DNA probes.

\section{INTRODUCTION}

Oral squamous cell carcinoma (OSCC) is the most common type of cancer of the mouth, accounting for more than $90 \%$ of all malignant oral neoplasms. Smoking and alcohol are considered to be the main etiological factors of OSCC. However, some patients develop this neoplasm without exposure to these risk factors, a fact suggesting the involvement of other etiological factors such as viral agents, particularly human papillomavirus (HPV) ${ }^{4,5,15,24,30 .}$

The role of HPV in the development of cancer of the uterine cervix has been well established, but the association between this virus and oral cancer is not well defined. Studies evaluating the role of HPV in 
oral carcinogenesis have yielded conflicting results, with the reported prevalence of HPV DNA in oral cancer tissue ranging from 0 to $100 \% 3,12,15,22,25,30$.

Cellular immunity seems to play an important role in the infection with HPV. The main cells involved in the elimination of altered cells are $\mathrm{T}$ lymphocytes. In the presence of an antigen, $T$ cells need to be activated and this activation is mediated by antigen-presenting cells, including Langerhans cells ${ }^{13,14}$.

Langerhans cells are found in the stratified epithelia of the epidermis and mucosa and their main function is to capture and transport protein antigens to the lymph nodes for effective presentation to T Iymphocytes ${ }^{13}$. Thus, Langerhans cells are able to induce either a cellular or a humoral immune response ${ }^{14,29}$.

Langerhans cells are believed to play an important role in tumor immunology, exerting a function against the emergence of new antigens expressing malignant transformation ${ }^{20}$. The major cells involved in killing cancer are the $T$ lymphocytes. However, T cells need to be activated upon antigen presentation, which is mediated by the antigen presenting cells, one of which is the Langerhans cell ${ }^{13,18}$.

Reduced immune surveillance may contribute to the severity of HPV-associated lesions ${ }^{8,12}$. Mota, et al. ${ }^{21}$ (1999) found a progressive decrease in the number of Langerhans cells with increasing severity of cervical intraepithelial lesions. In contrast, Levi, et al. ${ }^{16}$ (2005) observed an increase in the number of these cells with the progression of cervical neoplasms. In cancer of the uterine cervix, which is strongly associated with HPV, the onset and progression of this neoplasm are related to changes in Langerhans cells inside the squamous epithelium of this mucosa ${ }^{8,12}$.

The aims of the present study were to investigate the presence of HPV DNA and to compare the immunohistochemical staining of Langerhans cells between HPV-positive and HPV-negative cases of oscC.

\section{MATERIAL AND METHODS}

Twenty-seven cases of OSCC were used in this study. All specimens were taken from formalinfixed, paraffin-embedded tissues from files of the Oral Pathology Laboratory, School of Dentistry, Federal University of Rio Grande do Norte and from archives of Dr. Luis Antonio Hospital, Natal, RN, Brazil.

Of the 27 cases of OSSC evaluated, tumor primary sites included lip ( 7 cases), tongue (4 cases), floor of the mouth (5 cases) and other locations ( 9 cases). The mean patient's age was 63 years (range $30-93$ ), the sample comprised 19 men an 8 women.

Ten $10-\mu \mathrm{m}$ thick histological sections were obtained for DNA extraction and two 3- $\mu$ m sections were stained with hematoxylin/eosin for review by a pathologist.

DNA was extracted using the ammonium acetate-isopropanol technique which does not require the use of phenol-chloroform. This method consisted of the initial removal of paraffin by baths in xylene heated to $65^{\circ} \mathrm{C}$. Next, the tissues were hydrated in a decreasing ethanol series (absolute, $95 \%, 70 \%$ and $50 \%)$. Then, $400 \mu \mathrm{L}$ sterile lysis buffer ( $50 \mathrm{mM} \mathrm{NaCl}, 5 \mathrm{mM}$ Tris- $\mathrm{HCl}$, pH 8, $12.5 \mathrm{mM}$ EDTA, $\mathrm{pH} 8$, and $0.25 \%$ SDS) and proteinase $\mathrm{K}$ at a final concentration of $500 \mu \mathrm{g} / \mathrm{mL}$ were added to the tissue pellet of each sample and the samples were incubated at $55^{\circ} \mathrm{C}$ for 3 to 5 days until complete dissolution of the material. Next, $200 \mu \mathrm{L}$ of a $4 \mathrm{M}$ ammonium acetate solution was added to each sample for protein precipitation, followed by 600 $\mu \mathrm{L} 100 \%$ isopropanol for DNA precipitation. Finally, the DNA pellets obtained were washed with $70 \%$ ethanol, dissolved in $50 \mu \mathrm{L}$ TE buffer and stored at $-20^{\circ} \mathrm{C}$.

Polymerase Chain Reaction (PCR) was carried out in an Eppendorf thermocycler in a reaction mixture containing the following components in a final volume of $50 \mu \mathrm{L}: 0.5 \mu \mathrm{M}$ of the $\mathrm{PCO}_{3}$ and $\mathrm{PCO}_{4}$ primers (Invitrogen, Life Technologies, Carlsbad, CA, USA), $1.0 \mathrm{U}$ Taq DNA polymerase (Invitrogen, Life Technologies), 20 mM Tris- $\mathrm{HCl}, \mathrm{pH} 8.4,50 \mathrm{mM}$ $\mathrm{KCl}, 1.5 \mathrm{mM} \mathrm{MgCl}_{2}, 200 \mu \mathrm{M}$ dNTP (GE Healthcare, Little Chalfont, Bucknghamshire, UK), and 0.7 or 7 $\mu \mathrm{L}$ sample DNA. The PCR conditions for amplification of the B-globin gene were: initial denaturation at $95^{\circ} \mathrm{C}$ for $4 \mathrm{~min}$, followed by 40 cycles of amplification at $95^{\circ} \mathrm{C}$ for $1 \mathrm{~min}, 50^{\circ} \mathrm{C}$ for $1 \mathrm{~min}$ and $72^{\circ} \mathrm{C}$ for $1 \mathrm{~min}$, and a final extension step at $72^{\circ} \mathrm{C}$ for $10 \mathrm{~min}$. The PCR products were analyzed by electrophoresis on 2.5\% agarose gel (Nusieve, Cambrex Bio Science Rockland, Wokingham, Berkshire, United Kingdom) stained with ethidium bromide.

The samples positive for $B$-globin were analyzed by $P C R$ regarding the presence of HPV DNA using pair of generic primers GP5+ (5'TTTGTTACTGTGGTAGATACTAC3') and GP6+ (5'GAAAAATA AACTGTAAATCAT ATTC3'), which flank a fragment of about 140 bp of the L1 gene, a highly conserved sequence in the genome of mucosal (genital and oral) HPVs. The use of this primer pair permits the detection and amplification of this DNA segment from at least 23 individual mucosal (genital and oral) HPV types, including high-risk HPV types.

The reaction mixture contained $1.0 \mu \mathrm{M} \mathrm{GP5+/}$ GP6+ (Invitrogen, Life Technologies), $1.0 \mathrm{U}$ Taq DNA polymerase (Invitrogen, Life Technologies), $20 \mathrm{mM}$ Tris- $\mathrm{HCl}, \mathrm{pH} 8.4,50 \mathrm{mM} \mathrm{KCl}, 1.5 \mathrm{mM} \mathrm{MgCl}$, $200 \mu \mathrm{M}$ dNTP (GE Healthcare, Little Chalfont, 
Buckinghamshire, UK), and 0.7 to $7.0 \mu \mathrm{L}$ DNA, in a final volume of $50 \mu \mathrm{L}$. The PCR conditions for the detection of $\mathrm{HPV}$ were: initial denaturation at $95^{\circ} \mathrm{C}$ for $5 \mathrm{~min}$, followed by 40 cycles of amplification at $95^{\circ} \mathrm{C}$ for $1 \mathrm{~min}, 45^{\circ} \mathrm{C}$ for $2 \mathrm{~min}$ and $72^{\circ} \mathrm{C}$ for $1.5 \mathrm{~min}$, and a final extension step at $72^{\circ} \mathrm{C}$ for 10 min. The amplified PCR products were typed by dot blot hybridization ${ }^{23}$ using radioactive probes specific for the 19 HPV types most common in mucosal (genital and oral) infections. Each dot blot membrane included several negative and positive controls for HPV types, as well as PCR products from patients and controls. The membrane was hybridized overnight as $56^{\circ} \mathrm{C}$ in $2 x$ standard saline citrate (SSC), $0.5 \%$ sodium dodecyl sulfate (SDS) and $200 \mu \mathrm{g} / \mathrm{mL}$ DNA with $19 \mathrm{HPV}$ types probes $(6$ $, 11,16,18,31,33,34,35,39,40,42,43,44,45,51,52$, $54,56,58)$ and label $\left[{ }^{32}\right.$ P]dATP. After hybridization, the unbound probe was of $2 \times$ SSC and $0.5 \%$ SDS at room temperature and two 10-min washes of the same solution at $56^{\circ} \mathrm{C}$. The membrane was exposed to $\mathrm{x}$-ray film at $-20^{\circ} \mathrm{C}$ for $24 \mathrm{~h}$.

Immunohistochemical staining was performed on 3- $\mu \mathrm{m}$-thick formalin-fixed and paraffin-embedded sections. The sections were mounted on glass slides previously treated with organosilane as adhesive (3-aminopropyltrietoxi-silan, Sigma Chemical Co., St. Louis, MO, USA). The immunohistochemical technique used was a streptavidin-biotin method (streptavidin-biotin complex). The sections were incubated with antibody against S-100 protein (clone Cow S-100, Dako Corporation, Carpinteria, CA, USA), 1:200 dilution for $2 \mathrm{~h}$. The reaction was developed with diaminobenzidine as chromogen, and the sections were counterstained with Mayer's hematoxylin. Section from nervous tissue was used protein-positive control. In negative controls, the primary antibody was omitted.

After immunohistochemistry, the immunoreactive cells were analyzed taking into the presence or absence of immunostaining (positive, negative), following immunostaining density established by the determination of the number of cells positive in five fields of all specimens ${ }^{13,16}$. After the immunohistochemical analysis, these data were correlated with a presence of HPV.

The results were analyzed statistically by the Fish and Mann-Whitney test. A level of statistical significance of $5 \%$ was established for all tests. This research was approved by Research Ethics Committee of the Federal University of Rio Grande do Norte (Process number 146/05).

\section{RESULTS}

With respect to HPV infection, of the 27 cases analyzed, 9 (33.3\%) specimens were HPV-positive and $18(66.7 \%)$ were HPV-negative. HPV-18 was detected in all 9 HPV-positive cases (100\%) and infection with HPV-16 (co-infection) was detected in only 1 case (Figure 1 ).

The presence of Langerhans cells in the tumors was demonstrated by immunohistochemical staining for the anti-S-100 antibody, which resulted in a brown staining of the cytoplasm of cells with a dendritic shape (Figures 2 and 3 ). In the OSCC specimens analyzed, a mean number of $49.48 \pm 30.89$ Langerhans cells were stained for the anti-S-100 antibody, ranging from 6 to 139 cells present in five fields observed at $400 x$ magnification.

The median number of immunostained cells was smaller in HPV-positive cases (38 cells) compared to HPV-negative cases ( 42.5 cells), but this difference was not statistically significant $(p=0.382)$. Analysis of the presence or absence of HPV infection in relation to the number of S-100-stained Langerhans cells showed a wider variation in the number of immunostained cells in HPV-positive cases.

The possible association between the number of anti-S-100-positive Langerhans cells and HPV infection was also investigated. According with the median number of immunostained cells, cases were categorized into low (corresponding number of positive cells $\leq 38$ ) and high ( $>38$ positive cells). In the present sample, no significant association was

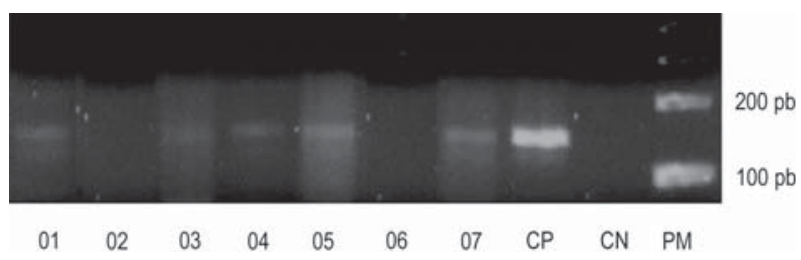

Figure 1-DNA detection by PCR in samples from patients with OSCC. Lanes 1-7: samples from patients; CP: Positive control- HeLa cell DNA infected with HPV18; CN: Negative control $\left(\mathrm{H}_{2} \mathrm{O}_{2}\right)$; PM: Molecular marker (100 pb)

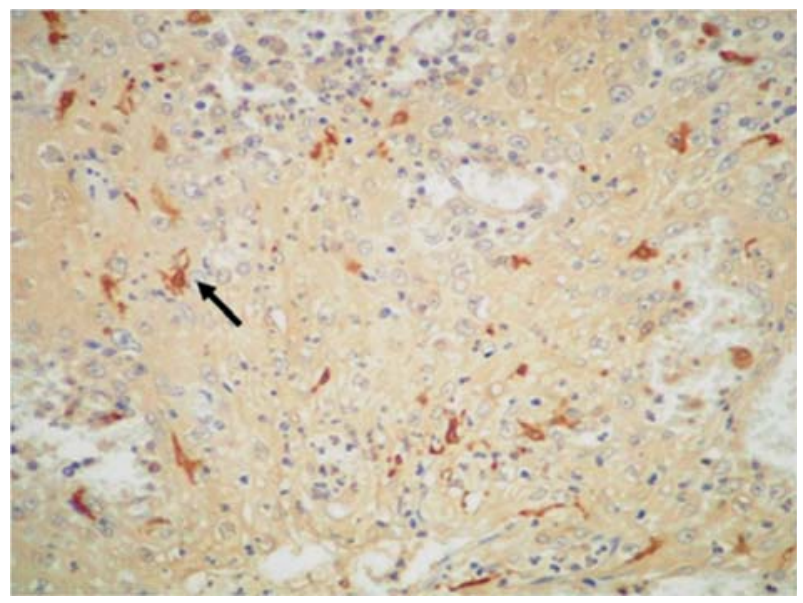

Figure 2- Immunostained Langerhans cells exhibiting characteristic dendritic shape. (SABC 400x) 


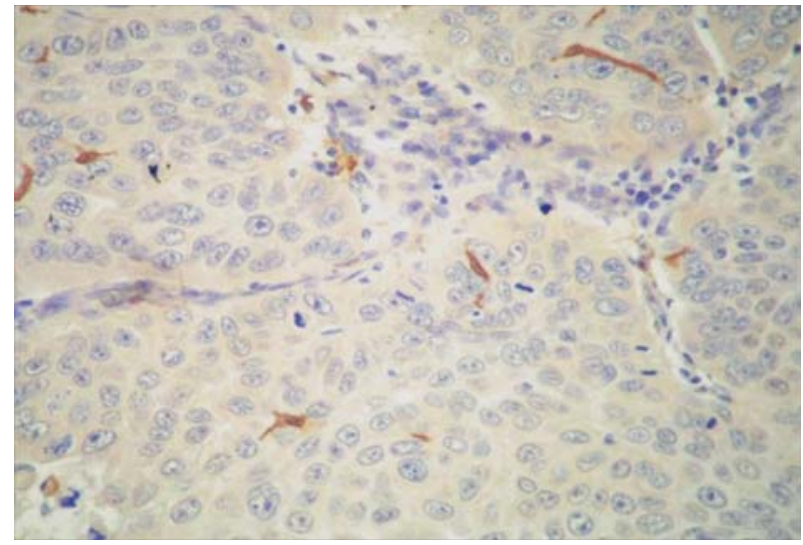

Figure 3- Immunostained Langerhans cells in a HPVpositive case of oral squamous cell carcinoma (SABC 400x)

Table 1- Cases categorized according with the median number of Langerhans cells immunostained, presence or absence of HPV infection and statistical significance

\begin{tabular}{cccc}
\hline HPV Infection & Low & High & $\mathbf{p}$ \\
& $\mathbf{n}(\%)$ & $\mathbf{n ~ ( \% )}$ \\
\hline Positive & $7(77.8 \%)$ & $2(22.2 \%)$ \\
Negative & $15(83.3 \%)$ & $3(16.7 \%)$ & $1,000^{* *}$ \\
\hline
\end{tabular}

${ }^{* *}$ Fisher test

observed between the number of S-100-stained Langerhans cells and HPV-positive or HPV-negative cases of OSCC $(p=1.000)$ (Table 1$)$.

\section{DISCUSSION}

Oral cancer is a multifactorial disease, with smoking and regular alcohol consumption being the main etiological agents involved in oral carcinogenesis ${ }^{30}$. However, these habits do not always explain the development of this type of neoplasm ${ }^{5,11}$.

Over the last few years, HPV has called the attention of researchers as a possible etiological agent of oral cancer ${ }^{1,10,15,24}$. This virus is strongly associated with cancer of the uterine cervix and is detected in almost $100 \%$ of cases of this neoplasm, but its role in oral carcinogenesis is still inconclusive $7,11,17,22,28,30$.

Several techniques have been used for the detection of HPV, with PCR being considered the most sensitive method $^{5}$. The most widely used primers are the generic primer pairs GP5+/GP6+ and MY09/MY11, which are able to amplify various virus types. In the present study, the presence or absence of HPV was confirmed by PCR using the GP5+/GP6+ primers because it amplifies a small fragment (140 bp). This is important when evaluating archived paraffin-embedded tissue, as done in the present study. Nine cases of the present sample (33.3\%) were HPV-positive and 18 (66.7\%) were HPV-negative. This percentage is similar to data reported elsewhere ${ }^{15,26}$.

HPV-18 was detected in all HPV-positive cases, in agreement with previous studies ${ }^{4,19,26}$, in which HPV-18 was the most frequent type. However, other investigators $1,3,11,15,17,28$ detected HPV-16 in 71\%, $35 \%, 66.6 \%, 55.6 \%, 33.3 \%$ and $85 \%$ of cases, respectively, with this virus type being the most prevalent.

Local cellular immunity plays an important role in the response to infection with HPV and its progression in terms of neoplastic alterations $\mathbf{s}^{6,8,9,12}$. Impaired immune function results in an increase of the frequency of clinically detected HPV infections ${ }^{8}$.

Langerhans cells are antigen-presenting and -processing cells present in the epithelium of skin and mucosa and are the main cell population responsible for the capture of antigens close to the epithelium, presenting these antigens to $T$ helper cells (CD4+ T lymphocytes) and thus inducing a specific immune response. A possible method for the evaluation of the patient's immune system is the investigation of Langerhans cells in the epithelium ${ }^{14,18}$.

It has been suggested that HPV infection exerts an immunosuppressive effect, reducing the number of Langerhans cells in the epithelium of lesions infected with this virus $\mathbf{s}^{6,9,12,21}$.

This suggestion has encouraged the present investigation, which analyzed the immunohistochemical staining of Langerhans cells in cases of OSCC infected with HPV, a fact not described in the literature.

All 27 OSCC specimens analyzed presented positive staining for Langerhans cells (S-100+), a finding also reported by Mota, et al. ${ }^{21}$ (1999), Sobhani, et al. ${ }^{27}$ (2002) and Karakök, et al. ${ }^{13}$ (2003), who investigated cases of OSCC, cervical intraepithelial lesions and laryngeal carcinoma, respectively.

In the present study, a mean number of 49.48 Langerhans cells were stained for the anti-S-100 antibody in each case. This result differs from those reported by Connor, et al. ${ }^{6}$ (1999), who observed 6.0 2.3 immunostained Langerhans cells in high-grade cervical intraepithelial lesions, and Karakök, et al. ${ }^{13}$ (2003), who found 5.3 \pm 7.9 S-100+ Langerhans cells in squamous cell carcinoma of the larynx. Hubert, et al. ${ }^{9}$ (2005) detected about 3 Langerhans cells in cervical carcinomas, whereas Levi, et al. ${ }^{16}$ (2005) found a mean number of 6.1 immunostained Langerhans cells in high-grade intraepithelial neoplasms. These discrepant results might be attributed to the heterogeneity in the types of lesions analyzed, as well as to the different sites of the lesions since, despite similarities, each mucosa presents its peculiarities. 
Miyagi, et al. ${ }^{20}$ (2001) detected a larger number of Langerhans cells in tumors infected with HPV (more than 100 cells per field) compared to lesions not infected with this virus (fewer than 10 cells per field) in specimens of adenocarcinoma and squamous cell carcinoma of the lung. In the present study, we found a wide variation in the number of immunostained cells, but no significant association was observed between the number of Langerhans cells and the presence of HPV in the OSCC cases analyzed. Our results agree with the findings of Uchimura, et al. ${ }^{29}$ (2004), who did not observe differences in the density of Langerhans cells in cervical lesions between HPV-positive and HPVnegative groups. However, these authors noted a change in the morphology of these cells from their characteristic dendritic shape to a more round shape in HPV-positive cases. This fact was not observed in the present study. This divergence between the two studies might reflect peculiarities in the site of the lesions, in view of the fact that the oral mucosa markedly differs from the cervical and pulmonary epithelium.

Although no significant association was observed between the number of Langerhans cells and the presence of HPV, the number of $\mathrm{S}-100+$ cells tended to be smaller in HPV-positive cases. In agreement with this observation, Connor, et al. ${ }^{6}$ (1999) and Jimenez-Flores, et al. ${ }^{12}$ (2006) found that Langerhans cells were significantly reduced in cases of HPV-positive cervical neoplasms compared to HPV-negative lesions. We agree with Arany and Tyring $^{2}$ (1998) who suggested that this depletion of Langerhans cells is apparently associated with replication of HPV since oncoproteins of this virus may affect antigen presentation.

Jimenez-Flores, et al. ${ }^{12}$ (2006) suggest that there is not a precise explanation for the decrease of dendritic cells found in the HPV-infected cervix, although several possibilities exist, including: reduction of the dendritic cells (or their immediate precursors) colonizing this area; increased exiting or traffic of the normally resident cells; or promoted dendritic cell death. They believe that the last possibility, although feasible, is less likely to occur because HPV is known to induce proliferation rather than cell death, at least in epithelial cells.

When classifying the mean number of Langerhans cells into high and low, we found no association between the number of these cells and HPV-positive or HPV-negative cases. Though, we believe that HPV infection might create a localized immunodeficient microenvironment. According to Gianini, et al.8 (2002) and Jimenez-Flores, et al. ${ }^{12}$ (2006), a consequence of this could be a more permissive microenvironment for the HPV to initiate and establish infection within the regional tissue, so local DC deficiency is likely to impede efficient T-cell recruitment into this microenvironment.

So far, no study is available correlating Langerhans cells and HPV in OSCC, a fact impairing the comparison of the present data with the literature on this specific neoplasm. HPV infection may provoke changes in the immune system by interfering with Langerhans cell-associated antigen presentation, permitting the escape from this defense mechanism. However, the present results showed no interference of HPV with Langerhans cells in the OSCC cases analyzed.

\section{CONCLUSION}

In conclusion, we observed no association between the immunostaining of Langerhans cells (S-100+) and infection with HPV in the OSCC cases analyzed. Despite the reduced sample analyses, mostly due to insufficient amount of tissue found in paraffin blocks for DNA extraction from various cases, which led to the exclusion these, our findings suggest that the presence of HPV in such cases of OSCC could not alter the immunological system, particularly the Langerhans cells. Further studies will be necessary to understand the real role between Langerhans cells and HPV in oral carcinogenesis.

\section{REFERENCES}

1- Anaya-Saavedra G, Ramirez-Amador V, Irigoyen-Camacho ME, García-Cuellar CM, Guido-Jiménez M, Méndez-Martínez. R, et al. High association of human papillomavirus infection with oral cancer: a case-control study. Arch Med Res. 2008;39:189-197.

2- Arany I, Tyring SK. Status of local cellular immunity in interferon-responsive and nonresponsive human papillomavirusassociated lesions. Sex Transm Dis. 1998;23:475-80.

3- Bouda M, Gorgoulis VG, Kastrinakis NG, Giannoudis A, Tsoli E, Danassi-Afentaki $D$, et al. "High risk" HPV types are frequently detected in potentially malignant and malignant oral lesions, but not in normal oral mucosa. Mod Pathol. 2000;13:644-53.

4- Boy S, Van Rensburg EJ, Engelbrecht S, Dreyer L, Van Heerden $M$, Van Heerden W. HPV detection in primary intra-oral squamous cell carcinomas - commensal, aetiological agent or contamination? J Oral Pathol Med. 2006;35:86-90.

5- Chaudhary AK, Singh M, Sundaram S, Mehrotra R. Role of human papillomavirus and its detection in potentially malignant and malignant head and neck lesions: updated review. Head Neck Oncol. 2009;1:22.

6- Connor JP, Ferrer K, Kane JP, Goldberg JM. Evaluation of Langerhans' cells in the cervical epithelium of women with cervical intraepithelial neoplasia. Gynecol Oncol. 1999;75:130-5.

7- Doorbar J. The papillomavirus life cycle. J Clin Virol. 2005;32:S7-15.

8- Giannini SL, Hubert P, Doyen J, Boniver J, Delvenne P. Influence of the mucosal epithelium microenviroment on Langerhans cells: implications for the development of squamous intraepithelial lesions of the cervix. Int J Cancer. 2002;97:654-9.

9- Hubert P, Caberg JH, Gilles C, Bousarghin L, Franzen-Detrooz E, Boniver J, et al. E-cadherin-dependent adhesion of dendritic and Langerhans cells to keratinocytes is defective in cervical human papilomavirus-associated (pre)neoplastic lesions. J Pathol. 2005;206:346-55. 
10- Iamaroon A, Pattanaporn K, Pongsiriwet S, Wanachantararak S, Prapayasatok S, Jittidecharaks S, et al. Analysis of 587 cases of oral squamous cell carcinoma in northern Thailand with a focus on young people. Int J Oral Maxillofac Surg. 2004;33:84-8.

11- Ibieta BR, Lizano M, Frías-Mendivil M, Barrera JL, Carrillo A, Ruiz-Godoy LM, et al. Human papilloma virus in oral squamous cell carcinoma in a Mexican population. Oral Surg Oral Med Oral Pathol Oral Radiol Endod. 2005;99:311-5.

12- Jimenez-Flores R, Mendez-Cruz R, Ojeda-Ortiz J, Muñoz-Molina R, Balderas-Carrillo O, Diaz-Soberanes ML, et al. High-risk human papilloma virus infection decreases the frequency of dendritic Langerhans' cells in the human female genital tract. Immunology. 2006; $117: 220-8$.

13- Karakök M, Bayazit YA, Ucak R, Özer E, Kanlikama M, Mumbuc $S$, et al. Langerhans cell related inflammatory reaction in laryngeal squamous cell carcinoma. Auris Nasus Larynx. 2003;30:81-4.

14- Keller R. Dendritic cells: their significance in health and disease. Immunol Lett. 2001;78:113-22.

15- Lee SY, Cho NH, Choi EC, Baek SJ, Kim WS, Shin DH, et al. Relevance of human papilloma virus (HPV) infection to carcinogenesis of oral tongue cancer. Int J Oral Maxillofac Surg. 2010;39:678-83.

16- Levi G, Feldman J, Holman S, Salarieh A, Strickler HD, Alter S, et al. Relationship between HIV viral load and Langerhans cells of the cervical epithelium. J Obstet Gynaecol Res. 2005;31:178-84. 17- Llamas-Martínez S, Esparza-Gómez G, Campo-Trapero J, Cancela-Rodríguez P, Bascones-Martínez A, Moreno-López LA, et al. Genotypic determination by PCR-RFLP of human papillomavirus in normal oral mucosa, oral leukoplakia and oral squamous cell carcinoma samples in Madrid (Spain). Anticancer Res. $2008 ; 28(6 \mathrm{~A}): 3733-41$.

18- Manickam A, Sivanandham M, Tourkova IL. Immunological role of dendritic cells in cervical cancer. Adv Exp Med Biol. 2007;601:155-62.

19- Mazon RC, Gerbelli TR, Benatti Neto C, Oliveira MRB, Donadi EA, Gonçalves MAG, et al. Abnormal cell-cycle expression of the proteins $\mathrm{p} 27, \mathrm{mdm} 2$ and cathepsin B in oral squamous-cell carcinoma infected with human papillomavirus. Acta Histochem. 2011;113(2):109-16
20- Miyagi J, Kinjo T, Tsuhako K, Higa M, Iwamasa T, Kamada Y, et al. Extremely high Langerhans cell infiltration contributes to favourable prognosis of HPV-infected squamous cell carcinoma and adenocarcinoma of the lung. Histopathology. 2001;38:355-67.

21- Mota F, Rayment N, Chong S, Singer A, Chain B. The antigenpresenting environment in normal and human papillomavirus (HPV)-related premalignant cervical epithelium. Clin Exp Immunol. $1999 ; 116: 33-40$.

22- Rivero ERC, Nunes FD. HPV in oral squamous cell carcinomas of a Brazilian population: amplification by PCR. Braz Oral Res. 2006;20:21-4.

23- Sambrook J, Russel, D. Molecular cloning. Philadelphia: CSHL; 2001.

24- Scully C. Oral cancer; evidence for sexual transmission. $\mathrm{Br}$ Dent J. 2005;199:203-7.

25- Siebers TJ, Merkx MA, Slootweg PJ, Melchers WJ, Van Cleef P, De Wilde PC. No high-risk HPV detected in SCC of the oral tongue in the absolute absence of tobacco and alcohol - a case study of seven patients. Oral Maxillofac Surg. 2008;12:185-8.

26- Soares RC, Oliveira MC, Souza LB, Costa ALL, Pinto LP. Detection of HPV DNA and immunohistochemical expression of cell cycle proteins in oral carcinoma in a population of Brazilian patients. J Appl Oral Sci. 2008;16:340-4.

27- Sobhani I, Walker F, Aparicio T, Abramowitz L, Henin D, Cremieux AC, et al. Effect of anal epidermoid cancer-related viruses on the dendritic (Langerhans') cells of the human anal mucosa. Clin Cancer Res. 2002;8:2862-9.

28- Sugiyama M, Bhawal UK, Dohmen T, Ono S, Miyauchi M, Ishikawa T. Detection of human papillomavirus-16 and HPV-18 DNA in normal, dysplastic, and malignant oral epithelium. Oral Surg Oral Med Oral Pathol Oral Radiol Endod. 2003;95:594-600. 29- Uchimura NS, Ribalta JCL, Focchi J, Simões MJ, Uchimura TT, Silva ES. Evaluation of Langerhans' cells in human papillomavirusassociated squamous intraepithelial lesions of the uterine cervix. Clin Exp Obstet Gynecol. 2004;31:260-2.

30- Uobe K, Masuno K, Fang YR, Li LJ, Wen YM, Ueda Y, et al. Detection of HPV in Japanese and Chinese oral carcinomas by in situ PCR. Oral Oncol. 2001;37:146-52. 